\title{
PVP-Protected Pt-Ru Nanoparticles as Highly Efficient Catalysts for Hydrogen Generation from Hydrolysis of Sodium Borohydride
}

\author{
Murat Rakap* \\ Maritime Faculty, Van Yuzuncu Yil University, 65080, Van, Turkey \\ Email: mrtrakap@gmail.com (M. R.)
}

\begin{abstract}
The employment of poly( $N$-vinyl-2-pyrrolidone) (PVP)-protected platinum-ruthenium nanoparticles $(3.2 \pm 1.4 \mathrm{~nm})$ as catalysts in the hydrolysis of sodium borohydride for hydrogen generation is reported. They have been prepared by co-reduction of two metal ions in ethanol/water mixture by an alcohol reduction method and characterized by UV-Vis spectroscopy, TEM-EDX analysis, and X-ray photoelectron spectroscopy. They are recyclable and highly efficient catalysts for hydrogen generation from the hydrolysis of sodium borohydride even at very low concentrations and temperature, providing record average turnover frequency (TOF) value (549 $\left.\mathrm{mol} \cdot \mathrm{H}_{2} / \mathrm{mol} \cdot \mathrm{cat} \cdot \mathrm{min}^{-1}\right)$ and maximum hydrogen generation rate $\left(16126 \mathrm{~L} \cdot \mathrm{H}_{2} \cdot \mathrm{min}^{-1}(\mathrm{~mol} \cdot \mathrm{cat})^{-1}\right)$. $\mathrm{Poly}(\mathrm{N}$-vinyl-2-pyrrolidone)-protected platinum-ruthenium nanoparticles also provide activation energy of $63.2 \pm$ $2 \mathrm{~kJ} \cdot \mathrm{mol}^{-1}$ for the hydrolysis of sodium borohydride.
\end{abstract}

Keywords platinum, ruthenium, nanoparticles, sodium borohydride, hydrogen

\section{Introduction}

The safe and efficient hydrogen storage materials have attracted worldwide interest to implement fuel cell based portable devices over the last two decades. ${ }^{[1]}$ Being a chemical hydride, sodium borohydride $\left(\mathrm{NaBH}_{4}, \mathrm{SBH}\right)$ appears to be suitable candidate for this purpose due to a number of advantageous properties such as the high hydrogen storage capacity $(10.8 \% \mathrm{wt})$ meeting the United States Department of Energy (US-DOE) criteria for hydrogen storage materials, the optimal control on hydrogen generation rate by supported catalysts, the acceptable hydrogen generation rate even at low temperature, high solubility in water, the availability and easy handling. ${ }^{[2-5]}$ Sodium borohydride can liberate hydrogen upon hydrolysis at room temperature in the presence of suitable catalysts according to Eq. (1).

$$
\mathrm{NaBH}_{4}(a q)+2 \mathrm{H}_{2} \mathrm{O}(l) \stackrel{\text { catalyst }}{\longrightarrow} \mathrm{NaBO}_{2}(a q)+4 \mathrm{H}_{2}(g)
$$

A number of catalysts including $\mathrm{Ru}(0)$ nanoclusters, ${ }^{[6]}$ electrodeposited $\mathrm{Co}$ and $\mathrm{Co}-\mathrm{P}^{[7]} \quad \mathrm{Ni}-\mathrm{C}-\mathrm{B},{ }^{[8]}$ Co-Mn-B nanocomposite, ${ }^{\left[{ }^{9]}\right.} \mathrm{Co}-\mathrm{B} / \mathrm{Ni}$ foam ${ }^{[10]} \mathrm{Co}-\mathrm{W}-\mathrm{B} / \mathrm{Ni}$ foam, ${ }^{[11]}$ electrolessly deposited Co-P, ${ }^{[12]}$ PVP-stabilized $\mathrm{Ni}(0)$ nanoclusters, ${ }^{[13]}$ Co-B/multi walled carbon nanotubes, ${ }^{[14]} \mathrm{Ni}-\mathrm{Ru}$ nanocomposite ${ }^{[15]} \mathrm{PtPd}$-carbon nanotubes ${ }^{[16]}$ intrazeolite $\mathrm{Co}(0)$ nanoclusters, ${ }^{[17]}$ polymer-stabilized $\mathrm{Co}(0) \mathrm{NCs},{ }^{[18]} \mathrm{Co}-\mathrm{Cr}-\mathrm{B},{ }^{[19]}$ porous $\mathrm{Fe}-\mathrm{Co}-\mathrm{B} / \mathrm{Ni}$ foam, ${ }^{[20]}$ clay-supported $\mathrm{Co}-\mathrm{B},{ }^{[21]} \mathrm{Co}-\mathrm{Ni}-\mathrm{B},{ }^{[22]}$ attapulgite $\mathrm{CoB},{ }^{[23]} \mathrm{Co}-\mathrm{Cu}-\mathrm{B},{ }^{[24]} \mathrm{NixB},{ }^{[25]} \mathrm{BMR} 07$ (Ni based), ${ }^{[26]}$ $\mathrm{Ru}-\mathrm{Pd}-\mathrm{Pt},{ }^{[27]} \mathrm{PVP} @ \mathrm{Ru}-\mathrm{Pd}$ nanoparticles, ${ }^{[28]} \mathrm{Ru}-\mathrm{RuO}_{2} / \mathrm{C}^{\left[{ }^{[29]}\right.}$ $\mathrm{SiO}_{2}$-supported $\mathrm{Fe}, \mathrm{Ni}$ and $\mathrm{Co},{ }^{[30]} \mathrm{Zr}-\mathrm{Co} / \mathrm{C},{ }^{[31]} \mathrm{Co}-\mathrm{P} / \mathrm{Cu},{ }^{[32]}$ $\mathrm{Pd}-\mathrm{Ni}-\mathrm{B}$ nanoclusters, ${ }^{[33]}$ mesoporous $\mathrm{Co}-\mathrm{B}^{[34]}$ and $\mathrm{Co} / \mathrm{Ni}$ foam ${ }^{[35]}$ have been identified to be effective for accelerating the hydrolysis of sodium borohydride.

Among these catalysts, nanoparticle-types provided good catalytic activities as expected due to the small particle sizes. However, the addition of second element to the monometallic nanoparticles will definitely improve the catalytic properties. Therefore, the employment of highly active bimetallic-type nanoparticles as catalysts for hydrogen generation from the hydrolysis of sodium borohydride has recently been focused. Herein, the employment of highly efficient poly $(N$-vinyl-2pyrrolidone)-protected platinum-ruthenium (Pt-Ru@PVP) nanoparticles for hydrogen generation from the hydrolysis of sodium borohydride is reported. They have recently been prepared by an alcohol reduction method, ${ }^{[36]}$ characterized by UV-Vis spectroscopy, TEM-EDX analysis, X-ray photoelectron spectroscopy, and employed as a highly efficient catalyst for hydrogen generation from the hydrolysis of ammonia borane ${ }^{[37]}$ which has prompted me to use them as catalysts in the hydrolysis of sodium borohydride. Although the cost of noble metal catalysts is assumed to be high, the high catalytic activity and recyclability of the Pt-Ru@PVP nanoparticles make them a very promising candidate to be used as a catalyst in developing efficient portable hydrogen generation systems using sodium borohydride as solid hydrogen storage material since it would compensate the cost concerns.

\section{Experimental}

\section{Materials}

Ruthenium(III) chloride trihydrate $\left(\mathrm{RuCl}_{3} \cdot 3 \mathrm{H}_{2} \mathrm{O}\right)$, hexachloroplatinic(IV) acid hexahydrate $\left(\mathrm{H}_{2} \mathrm{PtCl}_{6} \cdot 6 \mathrm{H}_{2} \mathrm{O}\right)$, poly $(\mathrm{N}$-vinyl-2pyrrolidone) (PVP-40) and sodium borohydride were purchased from Aldrich. Ethanol was purchased from Merck. Deionized water was distilled by a water purification system (Milli-Q system). All glassware and Teflon-coated magnetic stir bars were cleaned with acetone, followed by copius rinsing with distilled water before drying in an oven at $150^{\circ} \mathrm{C}$.

\section{Preparation of Pt-Ru@PVP nanoparticles}

Pt-Ru@PVP nanoparticles were prepared by an alcohol reduction method. Firstly, solutions of ruthenium(III) chloride trihydrate $(0.25 \mathrm{mmol}$ in $25 \mathrm{~mL}$ ethanol) and hexachloroplatinic(IV) acid hexahydrate $(0.25 \mathrm{mmol}$ in $25 \mathrm{~mL}$ water) were mixed and poly( $N$-vinyl-2-pyrrolidone) (PVP-40, $2.5 \mathrm{mmol}$ of monomeric units) was added to this solution as a protecting polymer. Then, the mixed solution was refluxed at $90^{\circ} \mathrm{C}$ for $2 \mathrm{~h}$. The formed Pt-Ru nanoparticles have brownish black color and 
are stable for months at room temperature. The total concentration of both metals was kept as $5.0 \mathrm{mM}$ in $50 \mathrm{~mL}$ of the mixed solution.

\section{Characterization of Pt-Ru@PVP nanoparticles}

UV-Vis analysis. UV-Vis spectra were recorded on a Cary 5000 (Varian) UV-Vis spectrophotometer. A quartz cell with a part length of $1 \mathrm{~cm}$ was used and spectra were collected over the range of $200-900 \mathrm{~nm}$.

TEM-EDX analysis. Transmission Electron Microscopy (TEM) analysis was carried out using a JEOL-2010 microscope operating at $200 \mathrm{kV}$, which is fitted with $\mathrm{LaB}_{6}$ filament and has lattice and theoretical point resolutions of 0.14 and $0.23 \mathrm{~nm}$, respectively. Samples were examined at magnification between 100 and $400 \mathrm{~K}$. One drop of dilute suspension of sample was deposited on the TEM grids and the solvent was then evaporated. The diameter of each particle was determined from the enlarged photographs.

X-Ray photoelectron spectroscopy. X-ray photoelectron spectrum (XPS) of the isolated nanoparticles was taken by using SPECS spectrometer equipped with a hemispherical analyzer and using monochromatic $\mathrm{Mg}-\mathrm{Ka}$ radiation (1250 eV, the X-ray tube working at $15 \mathrm{kV}$ and $350 \mathrm{~W}$ ).

${ }^{11} B$ NMR spectra. ${ }^{11} B$ NMR spectra were recorded on a Bruker Avance DPX 400 with an operating frequency of 128.15 $\mathrm{MHz}$ for ${ }^{11} \mathrm{~B}$. $\mathrm{D}_{2} \mathrm{O}$ and $\mathrm{BF}_{3} \cdot\left(\mathrm{C}_{2} \mathrm{H}_{5}\right)_{2} \mathrm{O}$ were used as a lock and external reference, respectively. At the end of the hydrolysis reaction, the resulting solutions were filtered and the filtrates were used for taking ${ }^{11} \mathrm{~B}$ NMR spectra.

Method to test the catalytic activity of Pt-Ru@PVP nanoparticles in the hydrolysis of sodium borohydride

The catalytic activity of Pt-Ru@PVP nanoparticles in the hydrolysis of sodium borohydride in aqueous solution was determined by measuring the rate of hydrogen generation. In all the experiments, a jacketed reaction flask $(50 \mathrm{~mL})$ containing a Teflon-coated stir bar was placed on a magnetic stirrer (Heidolph MR-301) and thermostated to $25.0 \pm 0.1{ }^{\circ} \mathrm{C}$ by circulating water through its jacket from a constant temperature bath. Then, a graduated glass tube $(40 \mathrm{~cm}$ in height and $2.5 \mathrm{~cm}$ in diameter) filled with water was connected to the reaction flask to measure the volume of the hydrogen gas to be evolved from the reaction. In a typical experiment, $284 \mathrm{mg}(7.47 \mathrm{mmol})$ of $\mathrm{NaBH}_{4}$ was dissolved in $20 \mathrm{~mL}$ of water. The solutions were transferred with a glass pipet into the reaction flask thermostated at $25.0 \pm 0.1{ }^{\circ} \mathrm{C}$. Then, aliquots of Pt-Ru@PVP nanoparticles from the stock solution $(5.0 \mathrm{mM})$ were added into the reaction flask. The experiment was started by closing the flask and the volume of hydrogen gas evolved was measured by recording the displacement of water level at the stirring speed of $900 \mathrm{rpm}$. In addition to the volumetric measurement of the hydrogen evolution, the conversion of sodium borohydride $(\delta-42.1)^{[38]}$ to metaborate $(\delta 9)^{[39]}$ was also checked by ${ }^{11}$ B NMR spectroscopy.

\section{Determination of activation energy for Pt-Ru@PVP nano- particles in the hydrolysis of sodium borohydride}

The hydrolysis of sodium borohydride $(0.375 \mathrm{M})$ catalyzed by Pt-Ru@PVP nanoparticles $(0.3 \mathrm{mM})$ was carried out by following the same way described in the previous section at various temperatures (in the range of $15,20,25,30$, and $35^{\circ} \mathrm{C}$ ) in order to obtain the activation energy $\left(E_{\mathrm{a}}\right)$ for the hydrolysis reaction.

Recyclability of Pt-Ru@PVP nanoparticles in the hydrolysis of sodium borohydride

The recyclability of Pt-Ru@PVP nanoparticles in the hy- drolysis of sodium borohydride was determined by a series of experiments started with a $20 \mathrm{~mL}$ solution containing $0.3 \mathrm{mM}$ Pt-Ru@PVP nanoparticles and $0.375 \mathrm{M}$ sodium borohydride at $25.0 \pm 0.1^{\circ} \mathrm{C}$. When the complete conversion is achieved, another equivalent of sodium borohydride was added to reaction mixture immediately. The results were expressed as retained\% initial catalytic activity of Pt-Ru@PVP nanoparticles versus the number of catalytic runs in the hydrolysis of sodium borohydride.

\section{Results and Discussion}

\section{Preparation and characterization of Pt-Ru@PVP nano- particles}

Pt-Ru@PVP nanoparticles were prepared from the co-reduction of mixture of hexachloroplatinic(IV) acid hexahydrate and ruthenium(III) chloride trihydrate by an alcohol reduction method in the presence of PVP in ethanol-water mixture at refluxing temperature. PVP serves as a stabilizer and a reducing agent. After refluxing for $2 \mathrm{~h}$, the color of the solution turned to brownish black, indicating the reductions of $\mathrm{Pt}^{4+}$ and $\mathrm{Ru}^{3+}$ ions to $\mathrm{Pt}^{0}$ and $\mathrm{Ru}^{0}$ to form their nanoparticles. Monitoring the UV-Vis electronic absorption spectra of the solution provides the best way to follow this conversion. Figure 1 shows the UV-Vis spectrum of the Pt-Ru@PVP nanoparticles from the reduction corresponding platinum and ruthenium salts by PVP. The absorption bands due to $\mathrm{d}$ - $\mathrm{d}$ transitions in $\mathrm{Pt}^{4+}$ and $\mathrm{Ru}^{3+}$ ions completely disappear after refluxing the solution, indicating the complete reduction of the corresponding ions. ${ }^{[37]}$

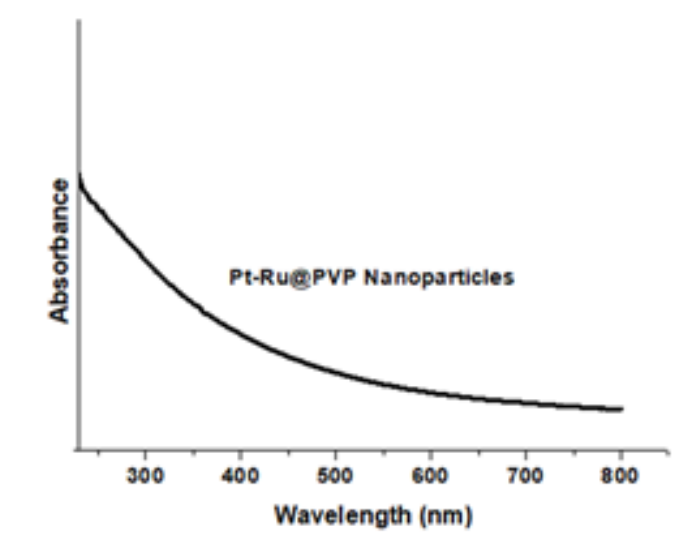

Figure 1 UV-Vis absorption spectrum of the Pt-Ru@PVP nanoparticles.

The size, morphology and composition of Pt-Ru@PVP nanoparticles were investigated by TEM-EDX analysis. Figure 2 shows TEM image taken at $50 \mathrm{~nm}$ magnification (Figure 2a) and the EDX spectrum (Figure 2b) of Pt-Ru@PVP nanoparticles. The mean particle size was determined as $3.2 \pm 1.4 \mathrm{~nm}$ from TEM image by counting non-touching particles.

Figure 3 shows the XPS spectrum of the Pt-Ru@PVP nanoparticles. The main peaks observed in the survey scan are $C$ 1s, Pt 4d, Pt 4f, Ru 3d, Ru 3p, and O 1s located at 285, $320-350,65-80,280-285,460-480$, and $530 \mathrm{eV}$, respectively. The XPS spectra for Pt $4 \mathrm{f}$ are characterized by a doublet containing a binding energy of $70.3 \mathrm{eV}$ for $4 \mathrm{f}_{7 / 2}$ and $73.8 \mathrm{eV}$ for $4 \mathrm{f}_{5 / 2}$, confirming the presence $\mathrm{Pt}(0){ }^{[40]}$ Due to the overlap of the $\mathrm{C} 1 \mathrm{~s}$ and $\mathrm{Ru} 3 \mathrm{~d}$ peaks around $285 \mathrm{eV}$, it is very difficult to analyze this region for ruthenium properly. The peak located at 462 $\mathrm{eV}$ for $\mathrm{Ru} 3 \mathrm{p}_{3 / 2}$ is readily assigned to the $\mathrm{Ru}(0) .{ }^{[41]}$ There is no higher oxidation state peak for both metals of the catalyst in the 

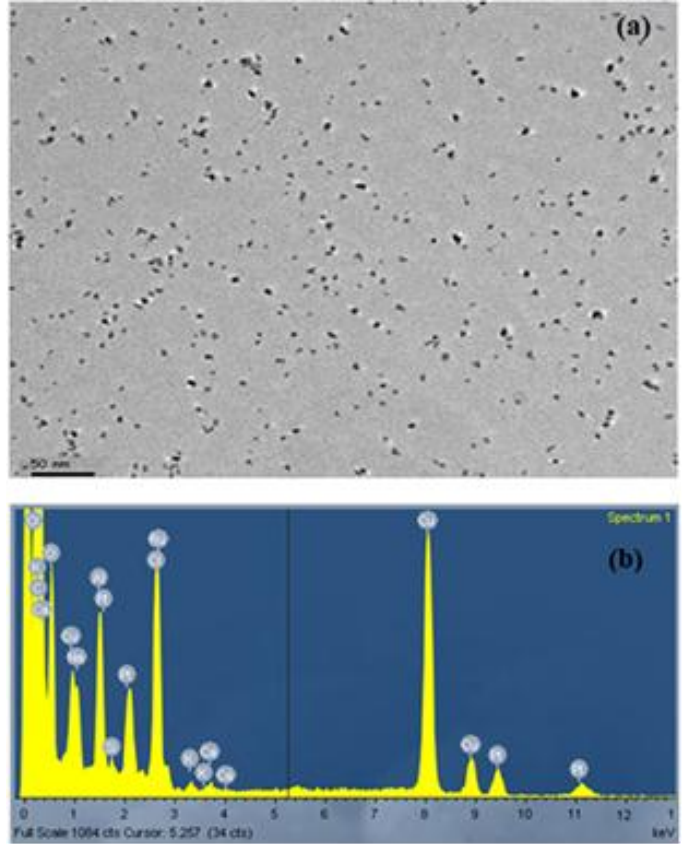

Figure 2 TEM image $(\mathrm{a}, 50 \mathrm{~nm})$ and the EDX spectrum (b) of Pt-Ru@PVP nanoparticles.

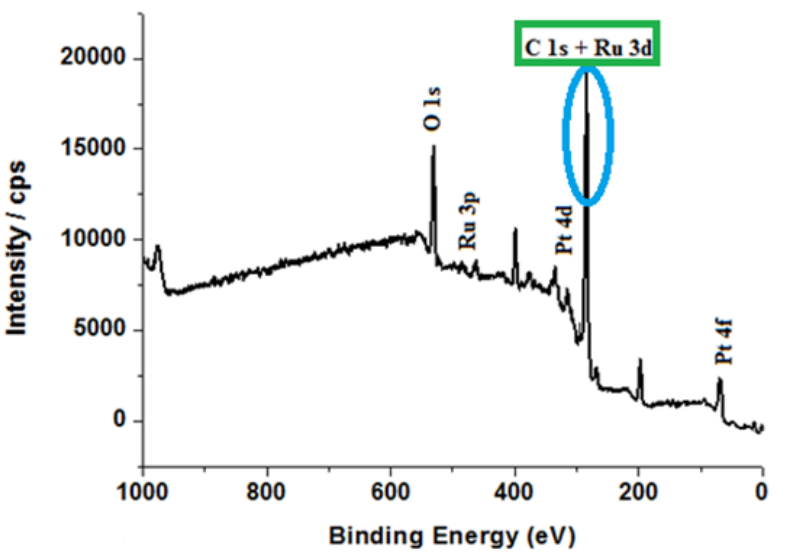

Figure 3 X-Ray photoelectron spectrum of Pt-Ru@PVP nanoparticles.

XPS spectra, indicating the protection of $\mathrm{Pt}(0)$ and $\mathrm{Ru}(0)$ species by the attachment of PVP during catalyst preparation procedure.

Additionally, the formation of PVP-protected Pt-Ru nanoparticles rather than the physical mixtures of individual monometallic nanoparticles was confirmed by comparing (not shown) the catalytic activities of all the types (monometallic Pt and $\mathrm{Ru}$ nanoparticles, their $1: 1$ physical mixture, and $1: 1 \mathrm{Pt}-\mathrm{Ru}$ bimetallic nanoparticles) in the hydrolysis of sodium borohydride. Pt-Ru@PVP nanoparticles provided a much higher catalytic activity than the physical mixture of $\mathrm{Pt}$ and $\mathrm{Ru}$ monometallic nanoparticles, clearly indicating that the prepared catalyst is composed of Pt-Ru@PVP bimetallic nanoparticles rather than a mixture of the individual monometallic nanoparticles. This much higher catalytic activity of bimetallic nanoparticles stems from the synergistic effects of platinum and ruthenium ${ }^{[42]}$ and the reduced particles size compared to the individual platinum (4.6 $\mathrm{nm})$ and ruthenium (4.2 nm) nanoparticles.
Testing the catalytic activity of Pt-Ru@PVP nanoparticles in the hydrolysis of sodium borohydride

Pt-Ru@PVP nanoparticles were found to be highly efficient catalyst for the hydrolysis of sodium borohydride. Figure 4 shows the plot of the volume of generated hydrogen gas versus time during the catalytic hydrolysis of $0.375 \mathrm{M} \mathrm{NaBH}_{4}$ solution in the presence of Pt-Ru@PVP nanoparticles in different catalyst concentrations at $25.0 \pm 0.1{ }^{\circ} \mathrm{C}$. The linear hydrogen generation starts immediately without an induction period and continues until the complete hydrolysis of sodium borohydride although the results in this figure show only $80 \%$ conversion of sodium borohydride to make the kinetic calculations.

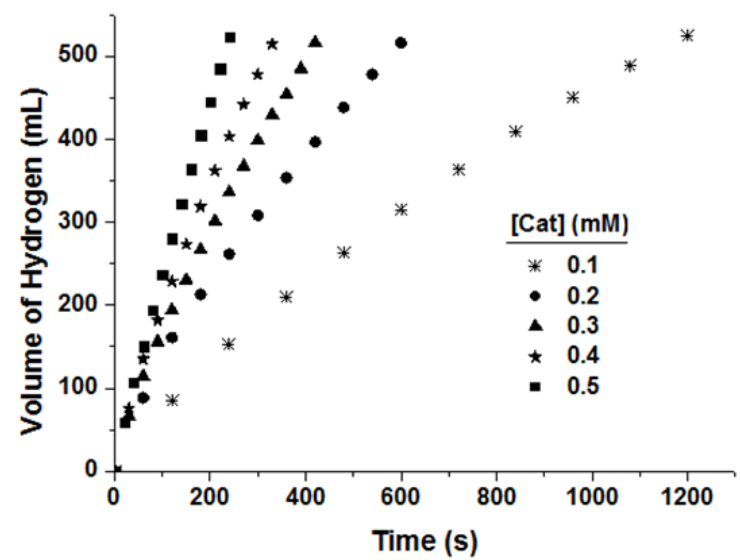

Figure 4 Plot of the volume of generated hydrogen gas versus time for the hydrolysis of $0.375 \mathrm{M}$ sodium borohydride solution in the presence of Pt-Ru@PVP nanoparticles in different catalyst concentrations at $25.0 \pm 0.1^{\circ} \mathrm{C}$.

Figure 5 shows the plot of the volume of generated hydrogen gas versus time in the hydrolysis of $\mathrm{NaBH}_{4}(0.375 \mathrm{M})$ solution catalyzed by Pt-Ru@PVP nanoparticles $(0.3 \mathrm{mM})$ at various temperatures in the range of $15-35^{\circ} \mathrm{C}$. It is worth to note that using Pt-Ru@PVP nanoparticles (0.3 mM) leads to $80 \%$ conversion for the hydrolysis of $\mathrm{NaBH}_{4}$ within $420 \mathrm{~s}$, providing record average turnover frequency (TOF) value of 549 $\mathrm{mol} \cdot \mathrm{H}_{2} / \mathrm{mol} \cdot \mathrm{cat} \cdot \mathrm{min}^{-1}$ and maximum hydrogen generation rate of $16126 \mathrm{~L} \cdot \mathrm{H}_{2} \cdot \mathrm{min}^{-1}$ (mol.cat) ${ }^{-1}$ at $25.0 \pm 0.1^{\circ} \mathrm{C}$. For comparison, maximum hydrogen generation rate values of some other catalyst are as follows: $460 \mathrm{~mL} \cdot \mathrm{H}_{2} \cdot \mathrm{min}^{-1}$ (g catalyst) ${ }^{-1}$ for Co-Ni-P/Pd-TiO $2,{ }^{[43]} 5000 \mathrm{~mL} \cdot \mathrm{H}_{2} \cdot \mathrm{min}^{-1}$ (g cobalt) ${ }^{-1}$ for $\mathrm{Co}(0)-$

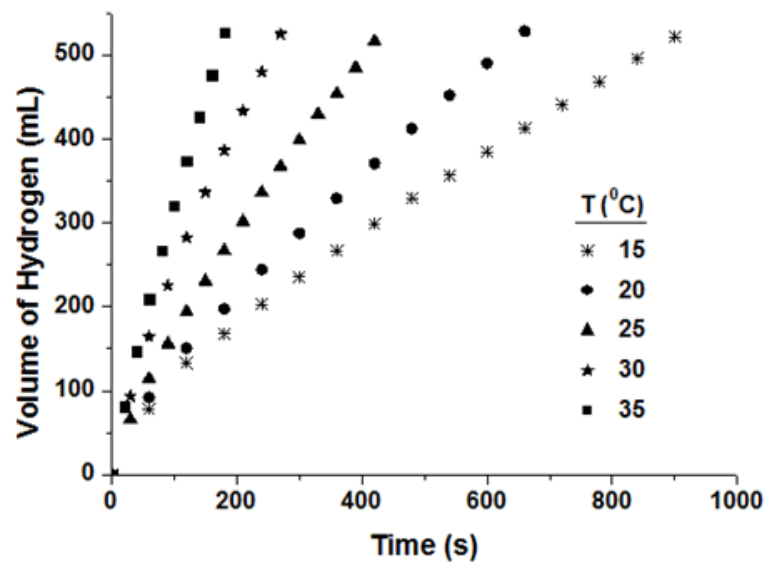

Figure 5 Plots of the volume of generated hydrogen gas versus time in the catalytic hydrolysis of $0.375 \mathrm{M} \mathrm{NaBH}_{4}$ solution in the presence of Pt-Ru@PVP nanoparticles $(0.3 \mathrm{mM})$ at various temperatures (in the range of $15-35^{\circ} \mathrm{C}$ ). 
HAP nanoparticles, ${ }^{[44]} 8701 \mathrm{~mL} \cdot \mathrm{H}_{2} \cdot \mathrm{min}^{-1} \quad$ (g cobalt $^{-1}$ for $\mathrm{Co} / \mathrm{SiO}_{2},{ }^{[30]} 307 \mathrm{~mL} \cdot \mathrm{H}_{2} \cdot \mathrm{min}^{-1}(\mathrm{~g} \text { nickel })^{-1}$ for $\mathrm{Ni} / \mathrm{SiO}_{2},{ }^{\left[{ }^{30]}\right.} 130$ $\mathrm{mL} \cdot \mathrm{H}_{2} \cdot \mathrm{min}^{-1}$ (g iron) ${ }^{-1}$ for $\mathrm{Fe} / \mathrm{SiO}_{2},{ }^{[30]} 1708 \mathrm{~mL} \cdot \mathrm{H}_{2} \cdot \mathrm{min}^{-1}(\mathrm{~g}$

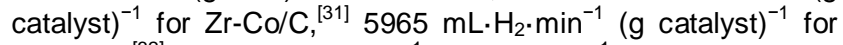
Co- $\mathrm{P} / \mathrm{Cu}^{[32]} 3350 \mathrm{~mL} \cdot \mathrm{H}_{2} \cdot \mathrm{min}^{-1}$ (g catalyst) ${ }^{-1}$ for mesoporous Co-B, ${ }^{[34]} 2650 \mathrm{~mL} \cdot \mathrm{H}_{2} \cdot \mathrm{min}^{-1}$ (g catalyst) ${ }^{-1}$ for $\mathrm{Co} / \mathrm{Ni}$ foam ${ }^{[35]} 400$ $\mathrm{mL} \cdot \mathrm{H}_{2} \cdot \mathrm{min}^{-1}$ (g catalyst) ${ }^{-1}$ for $\mathrm{Ni}-\mathrm{Ru}{ }^{[15]} 920 \mathrm{~L} \cdot \mathrm{H}_{2} \cdot \mathrm{min}^{-1}$ (g met$\mathrm{al}^{-1}$ for Pt-Pd-Ru, ${ }^{[27]} 300 \mathrm{~L} \cdot \mathrm{H}_{2} \cdot \mathrm{min}^{-1}$ (g metal) ${ }^{-1}$ for Pd-Pt/CNT, ${ }^{[4]}$ and $3100 \mathrm{~mL} \cdot \mathrm{H}_{2} \cdot \mathrm{min}^{-1}$ (g catalyst) ${ }^{-1}$ for $\mathrm{Pt}-\mathrm{LiCoO}_{2}{ }^{\left[{ }^{[3]}\right.}$

The apparent rate constants $\left(k_{\mathrm{app}}\right)$ of hydrogen generation from the hydrolysis of sodium borohydride were measured from the linear portions of each plot in Figure 5 at five different temperatures for the calculation of activation energy from the Arrhenius plot (Figure 6). The apparent Arrhenius activation energy $\left(E \mathrm{a}_{\text {app }}\right)$ was found to be $63.2 \pm 2 \mathrm{~kJ} \cdot \mathrm{mol}^{-1}$ for the hydrolysis of sodium borohydride. Keeping in mind that the activation energy is not a direct measure of catalytic activity, this activation energy value for the hydrolysis of sodium borohydride is lower than the activation energies reported in the literature for the same reaction using different catalysts: $76 \mathrm{~kJ} \cdot \mathrm{mol}^{-1}$ for Ru-promoted sulphated zirconia, ${ }^{[45]} 70 \mathrm{~kJ} \cdot \mathrm{mol}^{-1}$ for $\mathrm{Pt} / \mathrm{LiCoO}_{2},{ }^{[46]} 68 \mathrm{~kJ} \cdot \mathrm{mol}^{-1}$ for $\mathrm{Ru} / \mathrm{LiCoO}_{2},{ }^{[46]} 67 \mathrm{~kJ} \cdot \mathrm{mol}^{-1}$ for $\mathrm{Ru} / \mathrm{C}^{\left[{ }^{[47]}\right.}$ However, it is still higher than $55 \mathrm{~kJ} \cdot \mathrm{mol}^{-1}$ for Co-Mn-B nanocomposite, ${ }^{[9]} 56 \mathrm{~kJ} \cdot \mathrm{mol}^{-1}$ for Ru/IRA-400, ${ }^{[48]} 62 \mathrm{~kJ} \cdot \mathrm{mol}^{-1}$ for $\mathrm{Ni}-\mathrm{Co}-\mathrm{B},{ }^{[8]} 34 \mathrm{~kJ} \cdot \mathrm{mol}^{-1}$ for intrazeolite cobalt(0) nanoclusters ${ }^{[17]} 33 \mathrm{~kJ} \cdot \mathrm{mol}^{-1}$ for $\mathrm{Co}-\mathrm{B} / \mathrm{Ni}$ foam ${ }^{[10]} 38 \mathrm{~kJ} \cdot \mathrm{mol}^{-1}$ for $\mathrm{Ni}_{x} \mathrm{~B},{ }^{[25]} 28 \mathrm{~kJ} \cdot \mathrm{mol}^{-1}$ for Pd-C powder, ${ }^{[49]} 50 \mathrm{~kJ} \cdot \mathrm{mol}^{-1}$ for $\mathrm{Ru} / \mathrm{IR}-120,{ }^{[50]} 42 \mathrm{~kJ} \cdot \mathrm{mol}^{-1}$ for cobalt powder, ${ }^{[51]} 45 \mathrm{~kJ} \cdot \mathrm{mol}^{-1}$ for Co-B, ${ }^{[52]} 19 \mathrm{~kJ} \cdot \mathrm{mol}^{-1}$ for PtPd-carbon nanotubes, ${ }^{[4]}$ and 29 $\mathrm{kJ} \cdot \mathrm{mol}^{-1}$ for $\mathrm{Co}-\mathrm{W}-\mathrm{B} / \mathrm{Ni}^{\left[{ }^{[11]}\right.}$

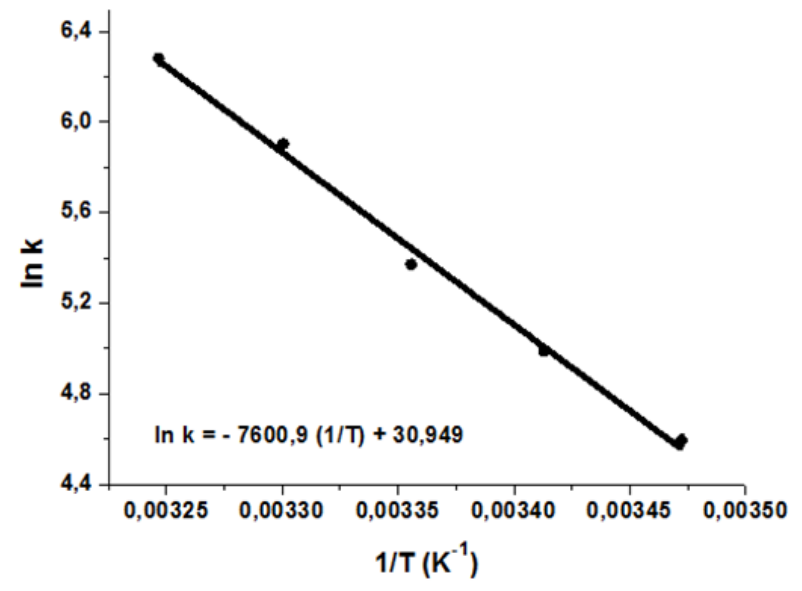

Figure 6 Arrhenius plot for the hydrolysis of sodium borohydride $(0.375 \mathrm{M})$ solution catalyzed by 0.3 mM Pt-Ru@PVP nanoparticles.

\section{Recyclability of Pt-Ru@PVP nanoparticles in the hydro- lysis of sodium borohydride}

The recyclability of Pt-Ru@PVP nanoparticles in the hydrolysis of sodium borohydride was investigated by successive additions of sodium borohydride after the first cycle of the hydrolysis reaction. Figure 7 shows the results of the recyclability tests for the hydrolysis of sodium borohydride catalyzed by Pt-Ru@PVP nanoparticles. The Pt-Ru@PVP nanoparticles catalyst retains $72 \%$ of its initial catalytic activity in the hydrolysis of sodium borohydride, even at the fifth run. The decrease in the catalytic activity of Pt-Ru@PVP nanoparticles in the hydrolysis of sodium borohydride is most probably due to the passivation of nanoparticles' surface by increasing amount of metaborate, which decreases accessibility of active sites ${ }^{[53]}$ and the aggregation of nanoparticles

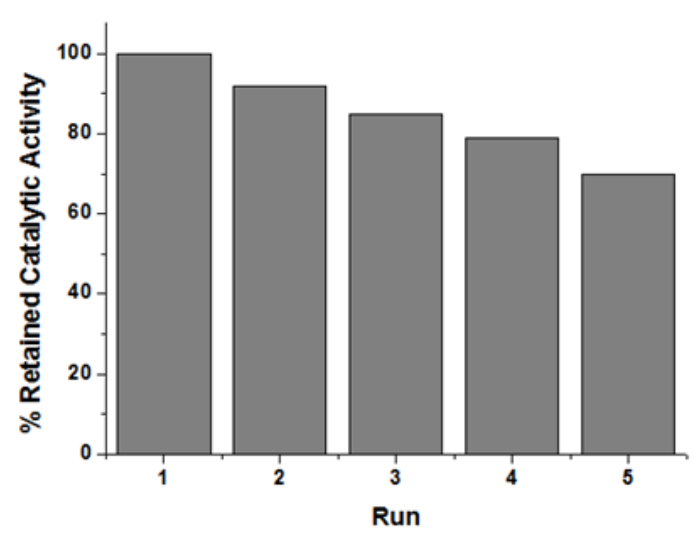

Figure 7 Retained\% catalytic activity of $0.3 \mathrm{mM}$ Pt-Ru@PVP nanoparticles in the successive catalytic runs for the hydrolysis of $0.375 \mathrm{M}$ sodium borohydride solution at $25.0 \pm 0.1^{\circ} \mathrm{C}$.

as shown in the TEM image of the catalyst taken after fifth run of the hydrolysis reaction.

\section{Conclusions and Perspectives}

In summary, the employment of Pt-Ru@PVP nanoparticles as a catalyst for the hydrolysis of sodium borohydride has led to the following conclusions and insights:

(1) Pt-Ru@PVP nanoparticles can be easily prepared from the co-reduction of corresponding platinum and ruthenium salts by an alcohol reduction method.

(2) Pt-Ru@PVP nanoparticles are highly efficient catalysts for hydrogen generation from the hydrolysis of sodium borohydride.

(3) They provide a record average TOF value (549 $\mathrm{mol} \cdot \mathrm{H}_{2} / \mathrm{mol} \cdot \mathrm{cat} \cdot \mathrm{min}^{-1}$ ) and maximum hydrogen generation rate (16126 L. $\left.\mathrm{H}_{2} \cdot \mathrm{min}^{-1}(\mathrm{~mol} \cdot \mathrm{cat})^{-1}\right)$ for the hydrolysis of sodium borohydride.

(4) Activation energy for the catalytic hydrolysis of sodium borohydride in the presence of Pt-Ru@PVP nanoparticles was calculated as $63.2 \pm 2 \mathrm{~kJ} \cdot \mathrm{mol}^{-1}$.

\section{Acknowledgement}

TEM-EDX and XPS analysis were conducted at the Central Laboratory of Middle East Technical University in Ankara.

\section{Conflict of Interest}

The author declare no conflict of interest.

Copyright (C) 2020 Murat Rakap. This article is an open access article distributed under the terms and conditions of the Creative Commons Attribution (CC BY) license (http://creativecommons.org/licenses/by/ 4.0/). The use, distribution or reproduction in other forums is permitted, provided the original author(s) or licensor are credited and that the original publication in this journal is cited, in accordance with accepted academic practice. No use, distribution or reproduction is permitted which does not comply with these terms.

\section{References}

[1] Xu, D.; Zhao, L.; Dai, P.; Ji, S. Hydrogen generation from methanolysis of sodium borohydride over $\mathrm{Co} / \mathrm{Al}_{2} \mathrm{O}_{3}$ catalyst. J. Nat. Gas Chem. 2012, 21, 488-494.

[2] Amendola, S. C.; Janjua, J. M.; Spencer, N. C.; Kelly, M. T.; Petillo, P. J.; Sharp-Goldman, S. L.; Binder, M. A safe, portable, hydrogen gas generator using aqueous borohydride solution and Ru catalyst. Int. J. Hydrog. Energy 2000, 25, 969-975.

[3] Kojima, Y.; Suzuki, K. I.; Fukumoto, K.; Sasaki, M.; Yamamoto, T.; 
Kawai, Y.; Hayashi, H. Hydrogen generation using sodium borohydride solution and metal catalyst coated on metal oxide. Int. J. Hydrog. Energy 2002, 27, 1029-1034.

[4] Alonso, R. P.; Sicurelli, A.; Callone, E.; Carturan, G.; Raj, R. J. A picoscale catalyst for hydrogen generation from $\mathrm{NaBH}_{4}$ for fuel cells. J. Power Sources 2007, 165, 315-323.

[5] Patel, N.; Guella, G.; Kale, A.; Miotello, A.; Patton, B.; Zanchetta, C.; Fernandes, R. Structured and nanoparticle assembled Co-B thin films prepared by pulsed laser deposition: A very efficient catalyst for hydrogen production. J. Phys. Chem. C 2008, 112, 6968-6976.

[6] Özkar, S.; Zahmakıran, M. Hydrogen generation from hydrolysis of sodium borohydride using $\mathrm{Ru}(0)$ nanoclusters as catalyst. J. Alloys Compd. 2005, 404-406, 728-731.

[7] Cho, K. W.; Kwon, H. S. Effects of electrodeposited Co and Co-P catalysts on the hydrogen generation properties from hydrolysis of alkaline sodium borohydride solution. Catal. Today 2007, 120, 298-304.

[8] Ingersoll, J. C.; Mani, N.; Thenmozhiyal, J. C.; Muthaiah, A. Catalytic hydrolysis of sodium borohydride by a novel nickelcobalt-boride catalyst. J. Power Sources 2007, 173, 450-457.

[9] Mitov, M.; Rashkov, R.; Atanassov, N.; Zielonka, A. Effects of nickel foam dimensions on catalytic activity of supported Co-Mn-B nanocomposites for hydrogen generation from stabilized borohydride solutions. J. Mater. Sci. 2007, 42, 3367-3372.

[10] Dai, H. B.; Liang, Y.; Wang, P.; Cheng, H. M. Amorphous cobalt-boron/nickel foam as an effective catalyst for hydrogen generation from alkaline sodium borohydride solution. J. Power Sources 2008, 177, 17-23.

[11] Dai, H. B.; Liang, Y.; Wang, P.; Yao, X. D.; Rufford, T.; Lu, M.; Cheng, H. M. High-performance cobalt-tungsten-boron catalyst supported on $\mathrm{Ni}$ foam for hydrogen generation from alkaline sodium borohydride solution. Int. J. Hydrog. Energy 2008, 33, 4405-4412.

[12] Eom, K. S.; Cho, K. W.; Kwon, H. S. Effects of electroless deposition conditions on microstructures of cobalt-phosphorous catalysts and their hydrogen generation properties in alkaline sodium borohydride solution. J. Power Sources 2008, 180, 484-490.

[13] Metin, Ö.; Özkar, S. Synthesis and characterization of poly( $N$-vinyl2-pyrrolidone)-stabilized water-soluble nickel( 0$)$ nanoclusters as catalyst for hydrogen generation from the hydrolysis of sodium borohydride. J. Mol. Cat. A: Chem. 2008, 295, 39-46.

[14] Huang, Y.; Wang, Y.; Zhao, R.; Shen, P. K.; Wei, Z. Accurately measuring the hydrogen generation rate for hydrolysis of sodium borohydride on multiwalled carbon nanotubes/Co-B catalysts. Int. J. Hydrog. Energy 2008, 33, 7110-7115.

[15] Liu, C. H.; Chen, B. H.; Hsueh, C. L.; Ku, J. R.; Jeng, M. S.; Tsau, F. Hydrogen generation from hydrolysis of sodium borohydride using $\mathrm{Ni}-\mathrm{Ru}$ nanocomposite as catalysts. Int. J. Hydrog. Energy 2009, 34, 2153-2163.

[16] Alonso, R. P.; Sicurelli, A.; Callone, E.; Carturan, G.; Raj, R. A picoscale catalyst for hydrogen generation from $\mathrm{NaBH}_{4}$ for fuel cells. J. Power Sources 2007, 165, 315-323.

[17] Rakap, M.; Özkar, S. Intrazeolite cobalt(0) nanoclusters as low-cost and reusable catalyst for hydrogen generation from the hydrolysis of sodium borohydride. Appl. Catal. B: Environ. 2009, 91, 21-29.

[18] Metin, Ö.; Özkar, S. Hydrogen generation from the hydrolysis of ammonia-borane and sodium borohydride using water-soluble polymer-stabilized cobalt(0) nanoclusters catalyst. Energy Fuels 2009, 23, 3517-3526.

[19] Fernandes, R.; Patel, N.; Miotello, A. Hydrogen generation by hydrolysis of alkaline $\mathrm{NaBH}_{4}$ solution with $\mathrm{Cr}$-promoted Co-B amorphous catalyst. Appl. Catal. B: Environ. 2009, 92, 68-74.

[20] Liang, Y.; Wang, P.; Dai, H. B. Hydrogen bubbles dynamic template preparation of a porous $\mathrm{Fe}-\mathrm{Co}-\mathrm{B} / \mathrm{Ni}$ foam catalyst for hydrogen generation from hydrolysis of alkaline sodium borohydride solution. J. Alloys Compd. 2010, 491, 359-365.

[21] Tian, H.; Guo, Q.; Xu, D. Hydrogen generation from catalytic hydrolysis of alkaline sodium borohydride solution using attapulgite clay-supported Co-B catalyst. J. Power Sources 2010, 195, 2136-2142.

[22] Patel, N.; Fernandes, R.; Bazzanella, N.; Miotello, A. Co-P-B catalyst thin films prepared by electroless and pulsed laser deposition for hydrogen generation by hydrolysis of alkaline sodium borohydride: A comparison. Thin Solid Films 2010, 518, 4779-4785.

[23] Fernandes, R.; Patel, N.; Miotello, A.; Filippi, M. Studies on catalytic behavior of $\mathrm{Co}-\mathrm{Ni}-\mathrm{B}$ in hydrogen production by hydrolysis of $\mathrm{NaBH}_{4}$. J. Mol. Cat. A: Chem. 2009, 298, 1-6.

[24] Ding, X. L.; Yuan, X.; Jia, C.; Ma, Z. F. Hydrogen generation from catalytic hydrolysis of sodium borohydride solution using Cobalt-Copper-Boride (Co-Cu-B) catalysts. Int. J. Hydrog. Energy 2010, 35, 11077-11084.

[25] Dong, H.; Yang, H. X.; Ai, X. P.; Cha, C. S. Hydrogen production from catalytic hydrolysis of sodium borohydride solution using nickel boride catalyst. Int. J. Hydrog. Energy 2003, 28, 1095-1100.

[26] Zhang, Q.; Wu, Y.; Sun, X.; Ortega, J. Kinetics of catalytic hydrolysis of stabilized sodium borohydride solutions. Ind. Eng Chem. Res. 2007, 46, 1120-1124.

[27] Hu, L.; Ceccato, R.; Raj, R. Ultrahigh figure-of-merit for hydrogen generation from sodium borohydride using ternary metal catalysts. J. Power Sources 2011, 196, 69-75.

[28] Rakap, M. Hydrolysis of sodium borohydride and ammonia borane for hydrogen generation using highly efficient poly $(N$-vinyl-2-pyrrolidone)-stabilized Ru-Pd nanoparticles as catalysts. Int. J. Green Energy 2015, 12, 1288-1300.

[29] Li, Y.; Zhang, Q.; Zhang, N.; Zhu, L.; Zheng, J.; Chen, B. H. $\mathrm{Ru}-\mathrm{RuO}_{2} / \mathrm{C}$ as an efficient catalyst for the sodium borohydride hydrolysis to hydrogen. Int. J. Hydrog. Energy 2013, 38, 13360-13367.

[30] Shih, Y. J.; Su, C. C.; Huang, Y. H.; Lu, M. C. SiO-supported ferromagnetic catalysts for hydrogen generation from alkaline $\mathrm{NaBH}_{4}$ (sodium borohydride) solution. Energy 2013, 54, 263-270.

[31] Zhang, X.; Wei, Z.; Guo, Q.; Tian, H. Kinetics of sodium borohydride hydrolysis catalyzed via carbon nanosheets supported Zr/Co. J. Power Sources 2013, 231, 190-196.

[32] Guo, Y.; Feng, Q.; Dong, Z.; Ma, J. Electrodeposited amorphous Co-P catalyst for hydrogen generation from hydrolysis of alkaline sodium borohydride solution. J. Mol. Catal. A: Chem. 2013, 378, 273-278.

[33] Liu, W.; Cai, H.; Lu, P.; Xu, Q.; Zhongfu, Y.; Dong, J. Polymer hydrogel supported $\mathrm{Pd}-\mathrm{Ni}-\mathrm{B}$ nanoclusters as robust catalysts for hydrogen production from hydrolysis of sodium borohydride. Int. J. Hydrog. Energy 2013, 38, 9206-9216.

[34] Gupta, S.; Patel, N.; Fernandes, R.; Kothari, D. C.; Miotello, A. Mesoporous Co-B nanocatalyst for efficient hydrogen production by hydrolysis of sodium borohydride. Int. J. Hydrog. Energy 2013, 38, 14685-14692.

[35] Paladini, M.; Arzac, G. M.; Godinho, V.; Jimenez De Haro, M. C.; Fernandez, A. Supported Co catalysts prepared as thin films by magnetron sputtering for sodium borohydride and ammonia borane hydrolysis. Appl. Catal. B: Environ. 2014, 158-159, 400-409.

[36] Toshima, N.; Hirakawa, K. Polymer-protected Pt/Ru bimetallic cluster catalysts for visible-light-induced hydrogen generation from water and electron transfer dynamics. Appl. Surf. Sci. 1997, 121, 534-537.

[37] Rakap, M. Hydrogen generation from hydrolysis of ammonia borane in the presence of highly efficient poly $(N$-vinyl-2-pyrrolidone)-protected platinum-ruthenium nanoparticles. Appl. Catal. A: Gen. 2014, 478, 15-20.

[38] Guella, G.; Zanchetta, C.; Patton, B.; Miotello, A. New insights on 
the mechanism of palladium-catalyzed hydrolysis of sodium borohydride from ${ }^{11}$ B NMR measurements. J. Phys. Chem. B 2006, 110, 17024-17033.

[39] Eom, K. S.; Cho, K. W.; Kwon, H. S. Hydrogen generation from hydrolysis of $\mathrm{NH}_{3} \mathrm{BH}_{3}$ by an electroplated Co-P catalyst. Int. J. Hydrog. Energy 2010, 35, 181-186.

[40] Tian, Z. Q.; Jiang, S. P.; Liang, Y. M.; Shen, P. K. Synthesis and characterization of platinum catalysts on multiwalled carbon nanotubes by intermittent microwave irradiation for fuel cell applications. J. Phys. Chem. B 2006, 110, 5343-5350.

[41] Handbook of X-ray Photoelectron Spectroscopy. Eds.: Wagner, C. D.; Riggs, W. M.; Davis, L. E.; Moulder, J. F.; Muilenberg, B. E. Perkin-Elmer Physical Electronics Division, Eden Prairie, 1979, p. 106.

[42] Jiang, H. L.; Xu, Q. Recent progress in synergistic catalysis over heterometallic nanoparticles. J. Mater. Chem. 2011, 21, 1370513725.

[43] Rakap, M.; Kalu, E. E.; Özkar, S. Cobalt-nickel-phosphorus supported on $\mathrm{Pd}$-activated $\mathrm{TiO}_{2}$ (Co-Ni-P/Pd-TiO $)$ as cost-effective and reusable catalyst for hydrogen generation from hydrolysis of alkaline sodium borohydride solution. J. Alloys Compd. 2011, 509, 7016-7021.

[44] Rakap, M.; Özkar, S. Hydroxyapatite-supported cobalt(0) nanoclusters as efficient and cost-effective catalyst for hydrogen generation from the hydrolysis of both sodium borohydride and ammonia-borane. Catal. Today 2012, 183, 17-25.

[45] Demirci, U. B.; Garin, F. Kinetics of Ru-promoted sulphated zirconia catalysed hydrogen generation by hydrolysis of sodium tetrahydroborate. J. Mol. Catal. A: Chem. 2008, 279, 57-62.

[46] Liu, Z.; Guo, B.; Chan, S. H.; Tang, E. H.; Hong, L. Pt and Ru dispersed on $\mathrm{LiCoO}_{2}$ for hydrogen generation from sodium borohydride solutions. J. Power Sources 2008, 176, 306-311.

[47] Zhang, Z. S.; Delgass, W. N.; Fisher, T. S.; Gore, J. P. Kinetics of Ru-catalyzed sodium borohydride hydrolysis. J. Power Sources 2007, 164, 772-781.

[48] Xia, Z. T.; Chan, S. H. Feasibility study of hydrogen generation from sodium borohydride solution for micro fuel cell applications. $J$. Power Sources 2005, 152, 46-49.

[49] Patel, N.; Patton, B.; Zanchetta, C.; Fernandes, R.; Guella, G.; Kale, A.; Miotello, A. Pd-C powder and thin film catalysts for hydrogen production by hydrolysis of sodium borohydride. Int. J. Hydrog. Energy 2008, 33, 287-292.

[50] Hsueh, C. L.; Chen, C. Y.; Ku, J. R.; Tsai, S. F.; Hsu, Y. Y.; Tsau, F.; Jeng, M. S. Simple and fast fabrication of polymer template-Ru composite as a catalyst for hydrogen generation from alkaline $\mathrm{NaBH}_{4}$ solution. J. Power Sources 2008, 177, 485-492.

[51] Liu, B. H.; Li, Z. P.; Suda, S. Nickel- and cobalt-based catalysts for hydrogen generation by hydrolysis of borohydride. J. Alloys Compd. 2006, 415, 288-293.

[52] Kim, S. J.; Lee, J.; Kong, K. Y.; Jung, C. R.; Min, I.; Lee, S. Y.; Kim, H. J.; Nam, S. W.; Lim, T. H. Hydrogen generation system using sodium borohydride for operation of a $400 \mathrm{~W}$-scale polymer electrolyte fuel cell stack. J. Power Sources 2007, 170, 412-418.

[53] Clark, T. J.; Whittell, G. R.; Manners, I. Highly efficient colloidal cobalt- and rhodium-catalyzed hydrolysis of $\mathrm{H}_{3} \mathrm{NBH}_{3}$ in air. Inorg. Chem. 2007, 46, 7522-7527. 